16. Carroll S., Knowles S. Clinical practice guideline: preterm prelabour rupture of the membranes / Institute of Obstetricians and Gynaecologists, Royal College of Physicians of Ireland and Directorate of Strategy and Clinical Care, Health Service Executive. 2013. Version 1.0. Guideline № 24:19.

17. Mohr T. Premature rupture of the membranes. Gynekol Endokrinol. 2009;5(1):28-36.
18. Romero R., Espinoza J., Goncalves L. F., Kusanovic J. P. Friel L., Hassan S. The role of inflammation and infection in preterm birth. Semin Reprod Med. 2007;25:21-39.

19. Romero R., Chaiworapongsa T., Savasan Z. A. et al. Clinical chorioamnionitis is characterized by changes in the expression of the alarmin HMGB1 and one of its receptors, sRAGE. J Matern Fetal Neonatal Med. 2012;25:558-567.

About authors:

Shakhbazova Violetta Anatolievna, Postgraduate, doctor Department for Obstetrics, Gynecology, and Perinatology for Professional In-Service Training and Refreshment Courses, Kuban State Medical University, Russia; tel.: +78612220114; e-mail: sor.violetta2010@yandex.ru

Autleva Susanna Ruslanovna, MD, Obstetrician-Gynecologist; Gynecologist and Fertility Expert, Kuban Medical Center, Russia; tel.: +78612521455

\title{
INVOKED VISUAL POTENTIALS IN THE STUDY OF THE VISUAL ANALYZER IN PATIENTS WITH DIFFUSE SCLEROSIS
}

\author{
Karpov S. M., Padgigova Z. B., Karpov A. S., Vishlova I. A.
}

Stavropol State Medical University, Stavropol, Russian Federation

\section{ВЫЗВАННЫЕ ЗРИТЕАЬНЫЕ ПОТЕНЦИААЫ В ИССАЕАОВАНИИ ЗРИТЕАЬНОГО АНАЛИЗАТОРА У БОАЬНЫХ С РАССЕЯННЫМ СКАЕРОЗОМ}

\author{
С. М. Карпов, 3. Б. Пажигова, А. С. Карпов, И. А. Вышлова \\ Ставропольский госуАарственный меАицинский университет, \\ Ставрополь, Российская ФеАерация
}

The Purpose of the study was to examine the neurophysiological characteristics of the visual analyzer in patients with multiple sclerosis (MS) to optimize early diagnosis of the disease.

The study involved 79 patients ( 57 women and 22 men), mean age was $34.31 \pm 4.7$ years with a confirmed diagnosis of multiple sclerosis.

The results of neurophysiological studies have shown that in MS the demyelination processes in the structures of the visual analyzer in a variety of light spectrum not occur equally. The most pronounced significant $(p<0.01)$ deviations in the parameters invoked visual potentials secondary progressive multiple sclerosis on the black and white checkerboard pattern was observed in patients with primary progressive multiple sclerosis and clinical form of the changeover point. The indicator of the latent period of the wave R100 was increased sharply and significantly $(p<0.001)$ differed from the control group. Amplitude analysis made it possible to note a significant decrease in the strength of the response wave N75-N100 black-and-white stimulus in all clinical groups, making up on average of $3,3 \mathrm{mV}$ (control of $8.5 \mu \mathrm{v}$ ). The indicator of the latent period, the red-yellow chess pattern wave R100 was significantly increased and significantly $(p<0.001)$ differed from the control group. Similar changes were observed in green-and-black checkerboard pattern. When examined 25 patients with MS revealed increased levels of IgG antibodies to myelin basic protein.

The changes lead to a sharp decrease in the response of the cortical reaction. The use of color pattern will largely contribute to improving the early diagnosis of multiple sclerosis.

Key words: invoked potentials, visual analyzer, multiple sclerosis

Изучены нейрофизиологические особенности зрительного анализатора у 79 больных с рассеянным склерозом для оптимизации ранней диагностики. Женщин было 57 , мужчин - 22, средний возраст больных 34,3 44,7 лет.

Результаты нейрофизиологического исследования показали, что при РС процессы демиелинизации в структурах зрительного анализатора на разный световой спектр протекают неодинаково. Наиболее выраженные достоверные $(p<0,01)$ отклонения по параметрам ВЗП на черно-белый шахматный паттерн наблюдались у больных с ВПРС и ППРС клинической формой. Показатель ла- 
тентного периода волны Р100 был резко увеличен и достоверно (p<0,001) отличался от показателей контрольной группы. Амплитудный анализ позволил отметить достоверное снижение силы ответа волны N75-N100 на черно-белый стимул во всех клинических группах, составляя при этом в среднем 3,3 мкВ (контроль 8,5 мкВ). Показатель латентного периода на красно-желтый шахматный паттерн волны Р100 был значимо увеличен и достоверно ( $<<0,001)$ отличался от контрольной группы. Такие же изменения были отмечены на зелено-черный шахматный паттерн. При обследовании 25 пациентов с PC было выявлено повышение уровня антител IgG к основному белку миелина.

Полученные изменения приводят к резкому снижению ответной корковой реакции. Использование цветного паттерна во многом будет способствовать улучшению ранней диагностики РС.

Ключевые слова: вызванные потенциалы, зрительный анализатор, рассеянный склероз

\section{$\mathrm{T}$} he prevalence of multiple sclerosis (MS) in the world and in our country is high $[1,3$, 7]. More recently, for the doctor, had no significant detection of the first clinical signs of MS, as all therapy is limited to symptomatic treatment. Given the current success of pharmacology, the results of the use of new drugs in the treatment of MS, early diagnosis of the disease plays a dominant role.

The purpose of the study was to examine the neurophysiological characteristics of the visual analyzer in patients with multiple sclerosis (MS) to optimize early diagnosis of the disease.

Material and Methods. The study involved 79 patients (57 women and 22 men), mean age was $34.31 \pm 4.7$ years with a confirmed diagnosis of multiple sclerosis. The studied patients were divided into the following age groups: aged 18-19 years was 39 (49.4\%), remitting clinical type of flow was observed in $32(40.5 \%)$, primary progressive in 3 patients $(3.8 \%)$, secondary progressive -4 patients $(5.1 \%)$. The number of patients aged $30-39$ years was $23(29.1 \%)$, including remitting clinical type of flow was observed in 9 (11.4\%), primary progressive, 6 patients $(7.6 \%)$, secondary progressive - in 8 patients (10.1\%). The number of patients aged 40-50 years was 17 (21.5\%), remitting clinical type of flow was observed in 4 patients $(5.0 \%)$, primary progressive - in 10 patients $(12.7 \%)$, secondary progressive -3 patients $(18.9 \%)$

The average duration of the disease, clinical form was as follows: for remitting clinical type of MS - 3.3 \pm 2.2 years, secondary progressive MS $9.1 \pm 4.2$ years, primary progressive MS $-2.7 \pm 1.9$ years. Damage assessment of functional systems and the degree of disability in patients with MS was conducted in the scores on the expanded disability scale (EDSS, Kurtzke J. F., 1983). Easy severity was consistent with the scores from 1 to $3(2.39 \pm 0.1)$, medium (from 4 to $6(5.3 \pm 1.1)$, severe degree of 7

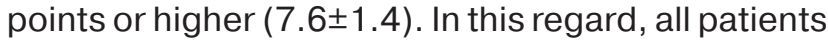
were divided into 2 groups according to severity.

Most patients were in a state of relative remission of the disease. The inclusion criterion was the presence of the patient of the diagnosis of MS, the presence of indicators of disease - frequency of clinically distinct exacerbations and the rate of growth of neurological deficit. Excluded persons with MS in the period of exacerbation of the disease, with a history of cranial trauma or neuroinfection.
To assess the visual analyzer was conducted neurophysiological study on the «NeuronSpectrum-4/VPM». Studied the latent period (LP) and the response amplitude invoked visual potentials (IVP) on the reverse black and white (BW), red-yellow (RY) and greenish black (GB) chess pattern (CHP). The advantage of this study is the clear selection in the graphical display of the fundamental wave R100, which corresponds to the activation of the 17th (primary visual cortex) and 18th (visual associative cortex) field Brodman [10]. The method allows to trace the nerve impulse along the optic fibers from the retinal cells (rods and cones, dipolar and ganglion cells) further along the optic nerve, through the optic tract and the structure of the mid-brain to the occipital lobe of the cerebral cortex. The method allows to quantify the speed of the visual analyzer in black-andwhite and color spectrum of visible light. The study was conducted according to standard methods. The active electrode was placed over the occipital region in the abstraction by 02,01 international scheme «10-20\%» and the ground electrode in the frontal region (point $\mathrm{Fpz}$ ). I psilateral electrode was located at the point of CZ. Impedance under the electrodes was not more than 10 ohms, the cell size 49'. Stimulation was conducted on alternating black-and-white - 1-I sample a color (red-yellow - 2nd test, green - 3rd test) chess pattern alternately on the left and right eyes, in a darkened room with the preliminary adaptation in the sitting position for one study. Estimated latent period component of the N75, P100 and N145 ms and the amplitude of the response - N75 - P100 mV. Comparative analysis of the obtained results was performed by a group of 30 healthy persons of the relevant sex and age of the patients with MS.

Thirty-six patients underwent laboratory tests, including determination of antibodies to myelin basic protein (MBP), which was determined by enzyme immunoassay [4].

To analyze the obtained results were used for the calculation of arithmetic mean values (M) and their errors $(m)$, confidence interval. The significance of differences of mean values was evaluated using Student's criterion ( $t$ ), we used the statistical software package SPSS 21.

Results and Discussion.Out of the total number of patients were allocated to the following clinical forms of the disease: remittent type of MS $45(56.9 \%)$ patients, secondary progressive type of MS - 15 (18.9\%) patients, the primary progressive type of MS - $19(24.2 \%)$ of patients. In the study 
group was dominated by patients with remittent type. In the group of patients with remittent type dominated by patients with mild disability. In the group of patients with secondary progressive type the number of patients with a medium degree of disability was increased 3 times, and severely - 5.5 times. In all groups of neurological symptoms were more likely to be impaired coordination and Central paresis of the limbs. More than $90 \%$ of patients with MS mild severity was observed only disturbance in the reflex field. It is known that visual impairment at a particular stage of disease revealed the overwhelming number of MS patients and at autopsy, the damage to the optic nerve is found in 94-95\% of cases [2, 5, 6, 8, 9].

Neurophysiological examination on the black and white checkerboard pattern has revealed that the most pronounced significant $(p<0.01)$ deviations in the parameters IVP relative to control group was observed in patients with secondary progressive type and primary progressive clinical form. So, LP N75 wave with data forms amounted $85,3 \mathrm{~ms}$, the indicator in remittent type also significantly $(p<0.01)$ differed from the parameters of the control group and amounted to $81,81 \mathrm{MS}$ (control group is $72.1 \pm 0.2 \mathrm{~ms}$ ). Indicator LP the most stable wave R100 was also increased sharply and significantly $(p<0.001)$ differed from the control group, regardless of the remittent type $127.09 \mathrm{~ms}$, secondary progressive type - to 128.3 $\mathrm{ms}$, when the primary progressive type $-124.5 \mathrm{~ms}$ (control group $106.1 \mathrm{~ms}$ ). LP indicator of the far field $(\mathrm{N} 145)$ also significantly $(p<0.01)$ was increased. We noted that only in $9(15 \%)$ patients of the total sample (all cases in the group with remittent type) LP wave R100 black-and-white pattern was within the control group, significantly exceeding the control values.

\begin{tabular}{|c|c|c|c|c|}
\hline \multicolumn{5}{|c|}{$\begin{array}{l}\text { Quantitative indicators IVP in patients } \\
\text { with different clinical forms of MS } \\
\text { black/white checkerboard pattern (M士SD) }\end{array}$} \\
\hline ndex & $\begin{array}{l}\text { Remittent } \\
\text { type } \\
(n=31)\end{array}$ & $\begin{array}{c}\text { Secondary } \\
\text { progressive } \\
\text { type } \\
(n=13) \\
\end{array}$ & $\begin{array}{c}\text { Primary } \\
\text { progressive } \\
\text { type } \\
(\mathrm{n}=16) \\
\end{array}$ & $\begin{array}{l}\text { Control } \\
\text { group } \\
(n=30)\end{array}$ \\
\hline $\begin{array}{l}\begin{array}{l}\text { Latent } \\
\text { period }\end{array} \\
\text { (ms) } \\
\text { N75 } \\
\text { P100 } \\
\text { N145 } \\
\\
\text { Ampli- } \\
\text { tude } \\
(\mu v)\end{array}$ & $\begin{array}{l}81.81 \pm 0.79 \\
{[80.19-} \\
83.42]^{*} \\
127.09 \pm 0.85 \\
{[125.37-} \\
128.82]^{*} \\
157.16 \pm 1.03 \\
{[155.05-} \\
159.27]^{*} \\
3.77 \pm 0.4 \\
{[3.54-4.00]^{*}} \\
\end{array}$ & $\begin{array}{l}85.31 \pm 0.80 \\
{[83.56-} \\
87.06]^{*} \\
128.31 \pm 1.06 \\
{[126.00-} \\
130.61]^{*} \\
159.23 \pm 1.16 \\
{[156.70-} \\
161.76]^{*} \\
3.50 \pm 0.7 \\
{[3.35-3.64]^{*}} \\
\end{array}$ & \begin{tabular}{|l}
$85.37 \pm 0.67$ \\
{$[83.94-$} \\
$86.80]^{*}$ \\
$124.50 \pm 1.50$ \\
{$[105.44-$} \\
$143.56]^{*}$ \\
$153.00 \pm 1.00$ \\
{$[140.29-$} \\
$165.70]^{*}$ \\
$3.30 \pm 0.15$ \\
{$[2.64-3.95]^{*}$} \\
\end{tabular} & $\begin{array}{l}72.1 \pm 0.2 \\
106.1 \pm 1.89 \\
148.3 \pm 1.41 \\
8.5 \pm 0.12\end{array}$ \\
\hline $\begin{array}{l}\text { The } \\
\text { Spear- } \\
\text { man } \\
\text { Corre- } \\
\text { lation } \\
\text { Wave } \\
\text { P100 }\end{array}$ & $\begin{array}{l}\text { Secondary } \\
\text { progressive } \\
-0.029 \\
\text { primary } \\
\text { progressive } \\
+0.193 \\
\text { control } \\
-0.074\end{array}$ & $\begin{array}{l}\text { Primary } \\
\text { progressive } \\
+0.141 \\
\text { remittent } \\
-0.029 \\
\text { control } \\
+0.423\end{array}$ & $\begin{array}{l}\text { remittent }+ \\
0.193 \\
\text { secondary } \\
\text { progressive } \\
+0.141 \\
\text { control } \\
+0.295\end{array}$ & \begin{tabular}{|l} 
remittent \\
-0.074 \\
secondary \\
progressive \\
+0.423 \\
primary \\
progressive \\
+0.295
\end{tabular} \\
\hline
\end{tabular}

Note: ${ }^{*}-95 \%$ confidence interval for the mean.
Amplitude analysis made it possible to note a significant decrease in the strength of the response wave N75-N100 black-and-white stimulus in all clinical groups, making up on average of $3.3 \mathrm{mV}$ at reference values of $8.5 \mathrm{mV}$. Greatest research interest was the analysis of the results on a color alternating checkerboard pattern. In the second sample was used for reverse red and yellow with a close range of visible light (red - wavelength 625-740 nm, yellow - wavelength 565-590 nm). The conducted research revealed significant changes in terms of LP, and amplitude response.

We noted that the most pronounced deviations in the parameters IVP significantly $(p<0.01)$ was observed in patients with secondary progressive type (Table 2). So, LP N75 wave is $91.85 \pm 0.53 \mathrm{~ms}$, LP at remittent type and the primary progressive type significantly $(p<0.01)$ were higher and amounted in the first case $89.55 \pm 0.49 \mathrm{~ms}$, in the second $-88.84 \pm 0.25$ $\mathrm{ms}$, (control group is $72.1 \pm 0.2 \mathrm{~ms}$ ). Indicator LP wave R100 was also increased sharply and significantly $(p<0.001)$ differed from the control group, regardless of the remittent type - 147.29 $\pm 1.19 \mathrm{~ms}$, secondary progressive type- $150.23 \pm 1.49 \mathrm{~ms}$, when the primary progressive type $-144.38 \pm 2.11 \mathrm{~ms}$ (control group 106.1 $1.89 \mathrm{MS}$ ). LP wave N 145 was significantly above control values. Correlation analysis (Spearman) made it possible to note significant correlation wave R100 mainly remittent type and secondary progressive type. Amplitude analysis has allowed to note the significant decrease in strength of response to red-yellow stimulus in all clinical groups, accounting for on average $2 \mathrm{mV}$ at reference values of $8.5 \mathrm{mV}$. clinical forms of MS on colored (red/yellow)
(red chess pattern $(\mathbf{M} \pm \mathbf{S D})$

\begin{tabular}{|c|c|c|c|c|}
\hline Index & $\begin{array}{c}\text { Remittent } \\
\text { type } \\
n=31\end{array}$ & $\begin{array}{c}\text { Secondary } \\
\text { progressive } \\
\text { type } \\
n=13\end{array}$ & $\begin{array}{c}\text { Primary } \\
\text { progressive } \\
\text { type } \\
n=16\end{array}$ & $\begin{array}{l}\text { Control } \\
\text { group } \\
n=30\end{array}$ \\
\hline $\begin{array}{l}\text { Latent } \\
\text { period } \\
\text { (ms) } \\
\text { N75 } \\
\text { P100 } \\
\text { N145 } \\
\text { Ampli- } \\
\text { tude } \\
(\mu \mathrm{v})\end{array}$ & $\begin{array}{l}89.55 \pm 0.49 \\
{[88.53-} \\
90.57]^{*} \\
147.29 \pm 1.19 \\
{[144.86-} \\
149.71]^{*} \\
180.77 \pm 0.98 \\
{[178.80-} \\
188.77]^{*} \\
2.02 \pm 0.07 \\
{[1.88-2.16]^{*}}\end{array}$ & $\begin{array}{l}91.85 \pm 0.53 \\
{[90.69-} \\
93.00]^{*} \\
150.23 \pm 1.49 \\
{[146.95-} \\
153.49]^{*} \\
180.30 \pm 1.45 \\
{[177.14-} \\
183.47]^{*} \\
2.00 \pm 0.1 \\
{[1.77-2.22]^{*}}\end{array}$ & $\begin{array}{l}88.84 \pm 0.25 \\
{[88.30-} \\
89.38]^{*} \\
144.38 \pm 2.11 \\
{[139.78-} \\
148.98]^{*} \\
180.92 \pm 1.70 \\
{[177.21-} \\
184.62]^{*} \\
2.12 \pm 0.12 \\
{[1.85-2.38]^{*}}\end{array}$ & $\begin{array}{l}72.1 \pm 0.2 \\
106.1 \pm 1.89 \\
148.3 \pm 1.41 \\
8.5 \pm 0.12\end{array}$ \\
\hline $\begin{array}{l}\text { The } \\
\text { Spear- } \\
\text { man } \\
\text { Corre- } \\
\text { lation } \\
\text { Wave } \\
\text { P100 }\end{array}$ & $\begin{array}{l}\text { Secondary } \\
\text { progressive } \\
+1.000 * * \\
\text { Primary } \\
\text { progressive- } \\
0.468 \\
\text { Control + } \\
0.170\end{array}$ & $\begin{array}{l}\text { Primary } \\
\text { progressive - } \\
0.468 \\
\text { remittent + } \\
1.000^{* *} \\
\text { Control + } \\
0.170\end{array}$ & $\begin{array}{l}\text { remittent - } \\
0.468 \\
\text { Secondary } \\
\text { progressive } \\
-0.468 \\
\text { Control + } \\
0.496\end{array}$ & $\begin{array}{l}\text { remittent } \\
+0.170 \\
\text { c Secondary } \\
\text { progressive } \\
+0.170 \\
\text { Primary } \\
\text { progressive } \\
+0.496\end{array}$ \\
\hline
\end{tabular}

Note: * - 95\% confidence interval for the mean value; ** significant correlation at the 0.01 level ( 1 sided).

The results of the green-black reverse NR, where the current pulse was sent to the mono color mode, visible light and only on the system cells-the cones 
with the wavelength range of $500-565 \mathrm{~nm}$, which is shorter than the wavelength of red and yellow (Table 3 ). In the sample IVP green color was statistically significant $(p<0.001)$ increase in the LP with all clinical forms of MS. The most significant lengthening of the LP wave N75 was when secondary progressive type $93.85 \pm 0.50 \mathrm{~ms}$. The results of the LP at remittent type and the primary progressive type were similar, amounting in the former case $90.55 \pm 0,5 \mathrm{~ms}$, in the second $89.43 \pm$ of $0.30 \mathrm{~ms}$ and significantly $(p<0,001)$ differed from the control group. Indicator LP wave R100 were significantly increased and significantly $(p<0.001)$ differed from the control group, regardless of the remittent type - 148.38 $\pm 1.21 \mathrm{~ms}$, secondary progressive type - 152.24 $\pm 1.51 \mathrm{~ms}$, primary progressive type -

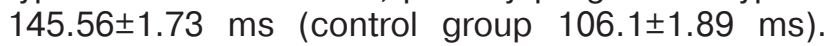
Changes in indicators of LP waves $145 \mathrm{~N}$ were also significantly changed. There was significant correlation was found between the groups on indicators IVP between remittent and secondary progressive type.

Table 3

The quantitative dynamics of HICP in patients with MS on a color (green/black) checkerboard pattern (M \pm SD)

\begin{tabular}{|c|c|c|c|c|}
\hline Index & $\begin{array}{c}\text { Remittent } \\
\text { type } \\
(n=31)\end{array}$ & $\begin{array}{c}\text { Secondary } \\
\text { progressive } \\
\text { type } \\
(n=13) \\
\end{array}$ & $\begin{array}{c}\text { Primary } \\
\text { progressive } \\
\text { type } \\
(n=16) \\
\end{array}$ & $\begin{array}{l}\text { Control } \\
\text { group } \\
(n=30)\end{array}$ \\
\hline $\begin{array}{l}\text { Latent } \\
\text { period } \\
\text { (ms) } \\
\text { N75 } \\
\text { P100 } \\
\text { N145 } \\
\text { Ampli- } \\
\text { tude ( } \mu \mathrm{v})\end{array}$ & $\begin{array}{l}90.55 \pm 0.5 \\
{[89.53-91.59]^{*}} \\
148.38 \pm 1.21 \\
{[145.90-} \\
150.86]^{*} \\
181.78 \pm 0.97 \\
{[179.77-} \\
183.67]^{*} \\
1.82 \pm 0.08 \\
{[1.68-1.96]^{*}}\end{array}$ & $\begin{array}{l}93.85 \pm 0.50 \\
{[92.69-95.12]^{*}} \\
152.24 \pm 1.51 \\
{[148.96-} \\
155.48]^{*} \\
182.32 \pm 1.49 \\
{[179.19-} \\
185.52]^{*} \\
1.76 \pm 0.06 \\
{[1.63-1.90]^{*}}\end{array}$ & $\begin{array}{l}89.43 \pm 0.30 \\
{[88.79-90.08]^{*}} \\
145.56 \pm 1.73 \\
{[141.86-} \\
149.25]^{*} \\
181.87 \pm 1.40 \\
{[178.87-} \\
184.87]^{*} \\
1.95 \pm 0.1 \\
{[1.73-2.17]^{*}}\end{array}$ & $\mid \begin{array}{l}72.1 \pm 0.2 \\
106.1 \pm 1.89 \\
148.3 \pm 1.41 \\
8.5 \pm 0.12\end{array}$ \\
\hline \begin{tabular}{|l|} 
The \\
Spear- \\
man \\
Corre- \\
lation \\
Wave \\
P100
\end{tabular} & $\begin{array}{l}\text { Secondary } \\
\text { progressive } \\
+0.996 * * \\
\text { Primary } \\
\text { progressive - } \\
0.411 \\
\text { Control } \\
+0.127\end{array}$ & $\begin{array}{l}\text { Primary } \\
\text { progressive } \\
-0.468 \\
\text { Remittent } \\
+0.996 * * \\
\text { Control } \\
+0.288\end{array}$ & $\begin{array}{l}\text { Remittent - } \\
0.411 \\
\text { Secondary } \\
\text { progressive } \\
-0.468 \\
\text { Control } \\
+0.030\end{array}$ & $\begin{array}{l}\text { Remittent } \\
++0.127 \\
\text { c Secondary } \\
\text { progressive } \\
+0.288 \\
\text { Primary } \\
\text { progressive } \\
++0.030\end{array}$ \\
\hline
\end{tabular}

Note: * - 95\% confidence interval for the average value; ** significant correlation at the 0.01 level ( 1 sided).

\section{References}

1. Alifirova V. M., Titova M. A. Clinical characteristics of multiple sclerosis in the Tomsk region. Nevrologiya, neiropsikhiatriya, psikhosomatika = Neurology, Neuropsychiatry, Psychosomatics. 2012;(2):50-51. doi:10.14412/2074-2711-2012-382.

2. Costello F., Coupland S., Hodge W., et al. Quantifying axonal loss after optic neuritis with optical coherence tomography. Ann Neurol. 2006;59(6):963-969. doi:10.1002/ana.20851.

3. Gnezditskii, V. V. Vyzvannye potentsialy mozga v klinicheskoi praktike [The caused potentials of a brain in clinical practice]. Taganrog: TRTU; 1997.

4. Karpov SM, Baturin VA, Tel'bukh VP, et al. Autoantitela to the main protein of a myelin and their role at the demiyeliniziruyushchikh processes. Klinicheskaya nevrologiya. 2013;(3):16-19.

5. Kubarko A. I., Kubarko N. P., Kubarko Ju. A. Light sensitivity of the visual system in patients with demyelinating optic neuropathy in acute retrobulbar neuritis. Zhurnal nevrologii i psikhiatrii im. S.S. Korsakova. 2014;114(22):40-47.
Amplitude analysis made it possible to note a significant decrease in the amplitude of the green-black stimulus wave N75-P100 in all clinical groups, not exceeding an average of $2 \mathrm{mV}$, which indicated the state's weak reaction to the visual cortex.

The results of the study suggest that the decrease in the amplitude of the response on the results of the IVP in different light wave bands associated with reduced impulse flow along the fibers of the visual analyzer and as a consequence a reduction in the number of neurons, which activate a response cortex to the stimulus.

The increase in LP visual analyzer in patients with MS is a consequence of demyelination processes. In this regard, to clarify these mechanisms, we performed immunological studies related to specifying the concentration of antibodies IgG to MBP, as a manifestation of a chronic immunological response. In the survey of 25 patients ( 17 with remittent type and 8 with secondary progressive type) revealed that the concentration level of IgG antibodies to MBP significantly $(p<0.001)$ higher than control group and amounted in the study $782.9 \pm 5.2 \mathrm{mg} / \mathrm{ml}$ (control group $50.1 \pm 2.12 \mathrm{mg} / \mathrm{ml}$ ). It should be noted that the increase of antibodies to MBP was identified in all cases.

Conclusions. Thus, the results of neurophysiological studies indicate that in MS the demyelination processes in the structures of the visual analyzer in a variety of light spectrum not occur equally. The most significant decrease of the LP occurs at a color spectrum of visible light relative to the black-and-white, which may serve as an early diagnostic criterion for this disease. These changes lead to a drastic reduction in cortical response due to decreased axonal conduction in fibers of the visual analyzer. We believe that the use of research results in clinical practice will largely contribute to improving the early diagnosis of MS.

6. Morquette J. B., Di Polo A. Dendritic and synaptic protection: is it enough to save the retinal ganglion cell body and axon? J. Neuroophthalmol. 2008;28(2):144-154. doi:10.1097/WNO.0b013e318177edf0.

7. Pazhigova Z. B., Karpov S. M., Shevchenko P. P., Burnusus N. I. Prevalence of multiple sclerosis in the world (review). Mezhdunarodnyi zhurnal eksperimental'nogo obrazovaniya. 2014;(1-2):78-82.

8. Rocca M. A., Hickman S. J., Bo L., et al. Imaging the optic nerve in multiple sclerosis. Multiple Scler. 2005;11(5):537-541. doi:10.1191/1352458505ms1213oa.

9. Shmidt T. E., Yakhno N. N. Rasseyannyi skleroz: rukovodstvo dlya vrachei [Multiple sclerosis: the guide for doctors]. 3nd ed. Moscow: MEDpress-inform; 2012. $272 \mathrm{p}$.

10. Zikhova A. R., Berezgova L. M., Tlapshokova L. B., Boiko A. N. Epidemiological characteristics of multiple sclerosis in the Kabardino-Balkaria Republic. Zhurnal nevrologii i psikhiatrii im. S.S. Korsakova. 2013;113(102):5-7 


\title{
VITAMIN D LEVELS IN NEWBORNS CHILDREN OF STAVROPOL REGION
}

Klimov L. Ja. ${ }^{1}$, Dolbnya S. V. ${ }^{1}$, Kuryaninova V. A. ${ }^{1}$, Alaverdyan L. S. ${ }^{1,2}$, Kasyanova A. N. ${ }^{1}$, Bobryshev D. V. ${ }^{1}$, Bondar T. P. ${ }^{3}$, Anisimov G. S. ${ }^{3}$, Abramskaya L. M. ${ }^{1}$

'Stavropol State Medical University, Stavropol, Russian Federation

2Stavropol Regional Clinical Perinatal Center, Stavropol, Russian Federation

${ }^{3}$ North-Caucasus Federal University, Stavropol, Russian Federation

\section{ОБЕСПЕЧЕННОСТЬ ВИТАМИНОМ D НОВОРОЖАЁННЫХ АЕТЕЙ СТАВРОПОАЬСКОГО КРАЯ}

А. Я. КАимов ${ }^{1}$, С. В. Аолбня ${ }^{1}$, В. А. Курьянинова ${ }^{1}$, А. С. А^аверАян ${ }^{1,2}$, А. Н. Касьянова А. В. Бобрышев ${ }^{1}$, Т. П. Бонаарь ${ }^{3}$, Г. С. Анисимов ${ }^{3}$, А. М. Абрамская ${ }^{1}$

\author{
${ }^{1}$ Ставропольский госуАарственный меАицинский университет, \\ Ставрополь, Российская ФеАерация \\ ${ }^{2}$ Ставропольский краевой клинический перинатальный центр, \\ Ставрополь, Российская ФеАерация \\ ${ }^{3}$ Северо-Кавказский фелеральный университет, Ставрополь, \\ Российская ФеАерация
}

Vitamin $D$ has a wide range of biological effects. There is evidence suggesting an important role of vitamin D in women's reproductive health, yet there has been no research focusing on newborns in South Russia. The purpose of this current study was to analyze the levels of vitamin D in newborns in the Stavropol Region. The clinical, anamnestic, and laboratory examination involved 60 newborns. The levels of vitamin $\mathrm{D}$ were assessed based on serum content of calcidiol, while the mothers' pregnancy courses were also taken into account. The mean content of serum $25(\mathrm{OH}) \mathrm{D}_{3}$ was $9.9 \pm 0.7 \mathrm{ng} / \mathrm{ml}$. The study showed that the vast majority of the patients (98.3\%) lacked vitamin D while in over a half of them (56.7\%) the deficiency was severe. It was shown that complicated somatic, obstetric and gynecological history is an important factor for antenatal hypovitaminosis $D$ in newborns $(p<0.05)$. In case of mothers' taking multivitamin preparations through pregnancies, severe vitamin D deficiency in newborns had an occurrence twice below that in infants whose mothers failed to take additional vitamin supply $(p<0.001)$. There is confirmation to the need for targeted antenatal prevention of hypovitaminosis $\mathrm{D}$ in order to reach proper levels of calciferol in the early neonatal period.

Key words: vitamin D, newborn, hypovitaminosis d, pregnancy failure, antenatal prophylaxis

Витамин D оказывает широкий спектр биологических эффектов. Имеются данные, указывающие на значимую роль витамина D в репродуктивном здоровье женщин, но до настоящего времени показатели у новорожденных юга России не изучались. Целью исследования был анализ обеспеченности витамином D новорождённых детей Ставропольского края. Проведено клинико-анамнестическое и лабораторное обследование 60 новорождённых. Обеспеченность витамином D оценивалась по содержанию кальцидиола в сыворотке крови, из анамнестических данных подробно анализировалось течение беременности у матери. Среднее содержание $25(\mathrm{OH}) \mathrm{D}_{3}$ сыворотки со-

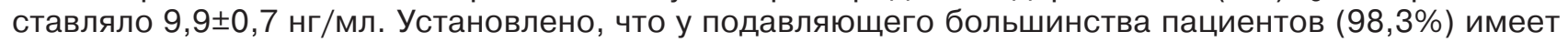
место недостаточное содержание витамина D, более половины $(56,7 \%)$ страдают тяжёлым дефицитом. Показано, что осложнённый соматический и акушерско-гинекологический анамнез являет- 